\title{
Immunodeficiency, HIV RNA plasma viral load and risk of AIDS-defining and non-AIDS-defining neoplasia, ANRS $\mathrm{CO} 3$ Aquitaine Cohort (1998-2006)
}

\author{
M Bruyand*1,2, R Thiebaut1,2,3, F Dabis ${ }^{1,2,3}$, S Lawson-Ayayi1,2, P Joly ${ }^{3}$, \\ AJ Sasco 1,3, P Mercie 1,2,3,4, JL Pellegrin'2,3,4, S Geffard ${ }^{1}$, D Neau ${ }^{2,3,4}$, \\ P Morlat $1,2,3,4$, G Chene ${ }^{1,2,3}$, F Bonnet ${ }^{1,2,3,4}$ for the Goupe D'Epidemiologie \\ Clinique Du Sida En Aquitaine (GECSA) ${ }^{1,2,3}$
}

Address: ${ }^{1}$ INSERM U897, Bordeaux, France, ${ }^{2} \mathrm{CHU}$ de Bordeaux, Coordination Régionale de la lutte contre l'infection due au VIH (COREVIH), Bordeaux, France, ${ }^{3}$ Université Victor Segalen Bordeaux 2, Bordeaux, France and ${ }^{4}$ Services de Médecine Interne et Maladies Infectieuses, CHU de Bordeaux, Bordeaux, France

* Corresponding author

\begin{abstract}
from I Ith International Conference on Malignancies in AIDS and Other Acquired Immunodeficiencies (ICMAOI): Basic, Epidemiologic, and Clinical Research

Bethesda, MD, USA. 6-7 October 2008

Published: 17 June 2009

Infectious Agents and Cancer 2009, 4(Suppl 2):O3 doi:I0.I I86/I750-9378-4-S2-O3
\end{abstract}

This abstract is available from: http://www.infectagentscancer.com/content/4/S2/O3

(c) 2009 Bruyand et al; licensee BioMed Central Ltd.

\section{Background}

The risk of neoplasis is increased in HIV-infected subjects. Beside traditional determinants of cancer occurrence, a specific role of HIV-related immunosuppression is strongly suspected and a more complex relationship between HIV and antiretroviral therapy (ART) cannot be excluded. Our objective was to disentangle the relationship between some frequently diagnosed cancers in HIVinfected patients and immunosuppression, HIV and ART exposure.

\section{Methods}

Patients from the ANRS CO3 Aquitaine Cohort were included in this study if they had a duration of follow-up of at least three months, at least two follow-up visits recorded within the study period (1998 to 2006) and if one HIV RNA plasma viral load (VL) was collected within the first follow-up visit. Durations of exposure were calculated as the time durations with CD4 count $<200$ and 500 cells $/ \mathrm{mm}^{3}$ or $\mathrm{VL}>500$ copies/mL. Multivariate modelling was based on extended Cox proportional hazards models for time-time dependent covariates and delayed entry (at time of first VL measurement). ART exposure was defined as the prescription of at least three antiretroviral drugs.

\section{Results}

Among the 4,194 patients included, 61 cases of NonHodgkin's lymphoma, 41 Kaposi's sarcoma, 41 bronchopulmonary and upper respiratory tract cancers, 20 skin cancers, 18 cases of Hodgkin's disease, 16 hepatocarcinomas and 14 anal cancers were reported during the study period. Kaposi's sarcoma was independently associated with each year spent with CD4 $<200$ (Hazard ratio $[\mathrm{HR}]=1.53 ; 95 \% \mathrm{CI}: 1.23-1.90 ; \mathrm{p}<0.001)$, each year of ART exposure (HR $=0.74 ; 95 \% \mathrm{CI}: 0.61-0.90 ; \mathrm{p}<0.003$ ) and male gender (HR = 5.26; 95\% CI: 1.66 - 16.66; $\mathrm{p}<$ $0.006)$. Non-Hodgkin's lymphoma was associated with each year spent with HIV RNA >500 ( HR $=1.34 ; 95 \% \mathrm{CI}$ : $1.19-1.51 ; \mathrm{p}<0.001)$, each year with CD4 $<200(\mathrm{HR}=$ $1.31 ; 95 \%$ CI: $1.12-1.53 ; \mathrm{p}<0.001)$, and each year of ART exposure (HR $=0.86 ; 95 \%$ CI: $0.75-0.99 ; \mathrm{p}<0.03$ ). Hepatocarcinoma was independently associated with each year spent with CD4 <500 (HR = 1.31; 95\% CI: 1.06 - 1.63; $\mathrm{p}=0.012$ ). Anal cancer was also independently associated with each year spent with HIV RNA >500 cop- 
ies/mL (HR $=1.31 ; 95 \% \mathrm{CI}: 1.02-1.68 ; \mathrm{p}=0.033)$. Regarding the associations between skin, anal and bronchopulmonary cancers and CD $4<200$, the adjusted analyses showed p-values of $0.058,0.112$ and 0.13 , respectively).

\section{Conclusion}

Together with immunosuppression, HIV VL may be independently associated with an increased risk of some cancers, AIDS-defining or not. Due to the limited statistical power to investigate several types of cancers that are still relatively infrequent, our results need to be confirmed by further studies, possibly collaborative and including lower-income country cohorts. Moreover, maintaining a high CD4 count, a strict control of HIV VL with fully suppressive ART could have a direct and measurable impact in preventing the currently predictable increasing occurrence of cancer in HIV-infected patients, in addition to other prevention policies.

Publish with Bio Med Central and every scientist can read your work free of charge

"BioMed Central will be the most significant development for disseminating the results of biomedical research in our lifetime. " Sir Paul Nurse, Cancer Research UK

Your research papers will be:

- available free of charge to the entire biomedical community

- peer reviewed and published immediately upon acceptance

- cited in PubMed and archived on PubMed Central

- yours - you keep the copyright

Submit your manuscript here:

http://www.biomedcentral.com/info/publishing_adv.asp 